\title{
Electrocoagulation-Adsorption to Remove Anionic and Cationic Dyes from Aqueous Solution by PV-Energy
}

\author{
J. Castañeda-Díaz, T. Pavón-Silva, E. Gutiérrez-Segura, and A. Colín-Cruz \\ Facultad de Química, Universidad Autónoma del Estado de México, Paseo Colón y Tollocan s/n, 50000 Toluca, MEX, Mexico \\ Correspondence should be addressed to T. Pavón-Silva; th.pavon@gmail.com
}

Received 13 December 2016; Revised 5 April 2017; Accepted 11 July 2017; Published 21 August 2017

Academic Editor: Davide Vione

Copyright (C) 2017 J. Castañeda-Díaz et al. This is an open access article distributed under the Creative Commons Attribution License, which permits unrestricted use, distribution, and reproduction in any medium, provided the original work is properly cited.

\begin{abstract}
The cationic dye malachite green (MG) and the anionic dye Remazol yellow (RY) were removed from aqueous solutions using electrocoagulation-adsorption processes. Batch and continuous electrocoagulation procedures were performed and compared. Carbonaceous materials obtained from industrial sewage sludge and commercial activated carbons were used to adsorb dyes from aqueous solutions in column systems with a 96-98\% removal efficiency. The continuous electrocoagulation-adsorption system was more efficient for removing dyes than electrocoagulation alone. The thermodynamic parameters suggested the feasibility of the process and indicated that the adsorption was spontaneous and endothermic $(\Delta S=0.037$ and -0.009 for $\mathrm{MG}$ and RY, resp.). The $\Delta G$ value further indicated that the adsorption process was spontaneous $(-6.31$ and $-10.48 ; T=303 \mathrm{~K})$. The kinetic electrocoagulation results and fixed-bed adsorption results were adequately described using a first-order model and a Bohart-Adams model, respectively. The adsorption capacities of the batch and column studies differed for each dye, and both adsorbent materials showed a high affinity for the cationic dye. Thus, the results presented in this work indicate that a continuous electrocoagulation-adsorption system can effectively remove this type of pollutant from water. The morphology and elements present in the sludge and adsorbents before and after dye adsorption were characterized using SEM-EDS and FT-IR.
\end{abstract}

\section{Introduction}

The contamination of surface water and groundwater with dyes is a serious environmental problem and a threat to human and aquatic life. Several studies have reported that more than 100,000 dyes are commercially available with an estimated annual production of over $7 \times 10^{5}-1 \times 10^{6}$ tons [1]. Industries that produce textiles, cosmetics, paper, leather, light-harvesting arrays, agricultural products, photoelectrochemical cells, pharmaceuticals, and food processing also produce large volumes of wastewater that are polluted with a high concentration of dyes and other components [2].

Malachite green (MG) is a cationic dye that is mainly used to dye textiles and paper; $M G$ is also used as a fungicide and antiparasitic agent in fishkeeping [3] and causes injuries to humans and animals after inhalation and ingestion. Its entry into the environment causes reduced human fertility and generates carcinogenic, mutagenic, and respiratory hazards $[4,5]$. Remazol yellow (RY) dye, or reactive yellow 105 , is an anionic dye used for textile dyeing due to its ease of use, colour stability, and resistance to washing [6]. The manufacture of azo dyes can impact the environment because of the presence of toxic amines in the effluent [7]. Moreover, dyes must be eliminated from wastewater before discharging it into water bodies. Due to the complex aromatic structure and synthetic origins of dyes, they are stable to heat, oxidizing agents, photodegradation, and biodegradation [8]. Several conventional methods can be applied to remove dyes from wastewater, including biological, physical, and chemical methods [9]. For example, coagulation is effective for sulphur and dispersive dyes. Acid, direct, vat, and reactive dyes coagulate but do not settle, while cationic dyes do not coagulate. Furthermore, chemical coagulation causes additional pollution (due to the undesired reactions in treated water) and produces large amounts of sludge $[10,11]$. Due to the large variability in the composition of textile wastewater, most 
<smiles>CN(C)c1ccc(C(=C2C=CC(=[N+](C)C)C=C2)c2ccccc2)cc1</smiles>

(a)<smiles>Nc1ccc(/N=N\c2ccc(S(=O)(=O)O)cc2)cc1S(=O)(=O)O</smiles>

(b)

FIgURE 1: Chemical structure of (a) malachite green and (b) Remazol yellow dyestuff.

conventional methods are expensive and are now becoming inadequate. Thus, there is an urgent need to develop more efficient and cost-effective techniques for the treatment of wastewater [12]. A combination of various techniques for the treatment of effluents can lead to higher removal efficiencies than a single treatment method.

Electrocoagulation technology is a simple, reliable, costeffective, and promising technique for treating various wastewaters without additional chemicals and thus reducing the volume of produced sludge; this technology requires only a low-intensity electrical current and can therefore be operated using green processes, such as solar cells, windmills, and fuel cells [2]. The coagulating agent is generated in situ during the electrooxidation of a sacrificial anode; the hydroxide formed on the mineral surfaces in situ is 100 times higher than on preprecipitated hydroxides when metal hydroxides are used as the coagulant. The flocs formed during electrocoagulation are relatively large and contain less bound water; therefore, they can easily be removed by filtration. The use of electrocoagulation with effluents containing low levels of dissolved solids is limited by the required minimum solution conductivity. During the removal of organic compounds from effluent-containing chlorides, toxic chlorinated organic compounds can form, and the sacrificial anodes must be replaced periodically; this method has high electricity costs and sludge production $[10,13]$. Therefore, electrocoagulation in combination with other treatment methods is a safe and effective method for dye removal.

Adsorption is a widely used, effective technology for dye removal treatment with applicability in wastewater treatment. Adsorption can also remove soluble and insoluble organic pollutants; the removal capacity of this method can reach 99.9\%. Adsorption is the accumulation of a substance at a surface or interface. In water treatment, the process occurs at an interface between a solid adsorbent and contaminated water. The adsorbed pollutant is called the adsorbate, and the adsorbing phase is called the adsorbent [14]. The most efficient methods are technologies based on the adsorption of activated carbon from water, which appears to be the best method for removing dyes. However, this process is expensive and difficult to regenerate after use [15]. Alternatively, sewage sludge-derived carbonaceous materials that act as sorbents have the advantage of providing economic value to waste as a material for producing adsorbents for the removal of pollutant materials. In addition, this application could solve the problem of sewage sludge pollution. Therefore, the feasibility of achieving cationic and anionic dye removal from aqueous solutions using a combined electrocoagulation and adsorption system composed of commercial activated carbon and sewage sludge-derived carbonaceous material as adsorbents was examined. The effects of the operating conditions on the performance of the electrocoagulation process in a batch reactor were evaluated; the combined process using electrocoagulation followed by adsorption in a sequenced continuous step was evaluated and compared. To the best of our knowledge, no such studies have been carried out previously. Finally, the Brunauer-Emmett-Teller (BET) surface area of the adsorbent and the sludge and dye-loaded adsorbents were characterized using FT-IR and SEM.

\section{Materials and Methods}

2.1. Materials. The carbonaceous material was obtained from industrial sewage sludge. The sludge feedstock and pyrolysis procedure have been described elsewhere [16]. Sludge pyrolysis was performed at $500^{\circ} \mathrm{C}$ for 60 min with a nitrogen flow rate of $350 \mathrm{~mL} \mathrm{~min}^{-1}$. The carbonaceous material was treated with a $10 \%$ hydrochloric acid solution at $20^{\circ} \mathrm{C}$ for $24 \mathrm{~h}$. Afterwards, it was washed five times with distilled water and dried at $70^{\circ} \mathrm{C}$ for $2 \mathrm{~h}$. Commercial granular activated carbon (CAC) from Clarimex ${ }^{\circledR}$, Mexico, was used for comparison. The materials were milled, sieved, and washed with deionized water to eliminate the fine particles. The grains with diameters between $0.42 \mathrm{~mm}$ and $0.84 \mathrm{~mm}$ were selected for both adsorbents.

2.2. Chemicals. MG chloride, a cationic dye (Figure 1(a)) (molecular formula: $\mathrm{C}_{23} \mathrm{H}_{25} \mathrm{~N}_{2} \mathrm{Cl}$, molecular weight: $365 \mathrm{~g} \mathrm{~mol}^{-1}$, and maximum light absorption: $\lambda_{\max }=617 \mathrm{~nm}$ ), is a commercial salt (Hycel, Mexico) and was used without further purification. RY is an anionic dye that is soluble in water and has a molar mass of $606 \mathrm{~g} \mathrm{~mol}^{-1}$ and maximum 
light absorption at $\lambda_{\max }=269 \mathrm{~nm}$. RY is a commercial salt (Dystar, Mexico), and its chemical structure is shown in Figure 1(b). MG and RY were selected and studied to compare the effectiveness of electrocoagulation-adsorption according to the type of dyestuff present. MG and YR dye solutions were used for preparing synthetic dye wastewater and were diluted to the desired concentration of $100 \mathrm{mg} \mathrm{L}^{-1}$.

2.3. Electrochemical Cell. Experiments were performed in batch and continuous modes with a 5.5-L rectangular reactor made of Perspex glass; the unit consisted of an electrochemical reactor and sludge separator. The volumes of the reactor and sludge separator were 2.5 and $3 \mathrm{~L}$, respectively. The two compartments were connected by a triangular groove, and the wastewater passed from the first compartment into the second by overflow. The solution was continuously circulated in the system using iron plates with a peristaltic pump (Masterflex L-S ${ }^{\circledR}$ ) at a flowrate of $65 \mathrm{~mL} \mathrm{~min}^{-1}$. Sodium chloride was added to the batch runs to achieve a solution conductivity of $69-78 \mathrm{mS} \mathrm{cm}^{-1}$.

Four plates $\left(100 \times 70 \times 1 \mathrm{~mm}^{3}\right)$ were used as electrodes with $70-\mathrm{cm}^{2}$ area. The gaps between the anodes and cathodes were maintained at $1 \mathrm{~cm}$. Each anode was placed between two cathodes to improve the current distribution. Magnetic stirrers were used to maintain a constant composition of feed wastewater. A solar cell supplied the system with 1$2 \mathrm{~A}$ of current intensity $\left(35.7 \mathrm{~A} \mathrm{~m}^{-2}-71.4 \mathrm{~A} \mathrm{~m}^{-2}\right)$. Samples $(10 \mathrm{~mL})$ were periodically taken from the reactor, and the dye concentrations were measured. This procedure was repeated twice. The dye concentration of the samples was calculated using a calibration curve that was prepared previously. The effects of the operating parameters were studied, and the optimal conditions of electrocoagulation for decolourization were determined.

The electrodes were treated with $\mathrm{HCl}(1 \mathrm{M})$ for cleaning prior to use to avoid passivation. After each run, the corroded parts of the anodes and electroreduced substances on the cathodes were removed with a revolving metal brush. The surfaces of the electrodes were replenished with sandpaper prior to each new experiment.

2.4. Fixed-Bed Experiments. The adsorption process was conducted using $17 \mathrm{~cm}$ bed heights in glass columns with a $2.2 \mathrm{~cm}$ internal diameter. The weights of the adsorbents were 36.5 and $33.9 \mathrm{~g}$ of carbonaceous material. The fixed-bed volumes for both adsorbents were $64.62 \mathrm{~cm}^{3}$. The used carbonaceous material was a residual sludge from a wastewater treatment plant, and we sought to determine and compare the applicability of an absorbent after a pyrolysis treatment and that of commercial activated carbon. Glass wool was placed in the bottom of the column to support the adsorbent. A volumetric flow rate of $40 \mathrm{~mL} \mathrm{~min}^{-1}$, corresponding to a hydraulic charge of $152 \mathrm{~m}^{3} \mathrm{~m}^{-2}$ day $^{-1}$, was calculated according to a previous report [17]. Liquid samples were withdrawn at different time points.

2.5. Analytical Procedure. The dye concentration was measured using a UV/vis spectrophotometer (Perkin Elmer model LAMBDA 125) at a wavelength corresponding to the maximum absorbance of each dye. The samples were filtered with Whatman paper number 1 every $5 \mathrm{~min}$ for analysis. The colour removal efficiency $(R, \%)$ after each treatment was calculated using the following formula:

$$
R(\%)=\frac{\left(C_{0}-C_{e}\right)}{C_{0}} 100 .
$$

where $C_{0}$ and $C_{e}$ are the concentrations of dye before and after electrocoagulation, respectively. The faradic yield of the metal dissolution $(\Phi)$ was estimated according to Faraday's law:

$$
\Phi=\frac{M I t}{n F} .
$$

where $\Phi$ is the amount of iron dissolution $(\mathrm{g}), M$ is the molecular weight of the iron $\left(55.85 \mathrm{~g} \mathrm{~mol}^{-1}\right), n$ is the number of electron moles $(n=2)$, and $F$ is the Faraday constant $(F=$ $\left.96,487 \mathrm{C} \mathrm{mol}^{-1}\right)$. The conductivity and $\mathrm{pH}$ were measured using a multiparameter instrument (Conductronic $\mathrm{pH}-15$ ), and a voltmeter (Fluke 179) was used to measure the voltage during the electrocoagulation process.

The rate of dye removal during electrocoagulation can be represented as follows:

$$
\frac{d C}{d t}=-k C^{m}
$$

where $C$ represents the dye concentration, $m$ represents the order of the reaction, $k$ represents the reaction rate coefficient, and $t$ represents the time. For a first-order reaction, the above equation becomes the following:

$$
\ln \frac{[C]}{C_{0}}=-k t .
$$

where $C_{0}$ is the initial dye concentration [18].

The rate of adsorption and the adsorbed amount of cationic and anionic dye on the materials were calculated using a breakthrough curve obtained by plotting $C_{e} / C_{0}$ (effluent concentration/influent concentration) versus time. The experimental results were adjusted to the Bohart-Adams model using Origin 8.0 software. The expression used is as follows [11]:

$$
\frac{C_{e}}{C_{0}}=\exp \left(k_{\mathrm{AB}} C_{0} t-k_{\mathrm{AB}} N_{0} \frac{Z}{F}\right) .
$$

where $k_{\mathrm{AB}}$ is the kinetic constant $\left(\mathrm{Lmg}^{-1} \mathrm{~min}^{-1}\right), F$ is the linear flow rate $\left(\mathrm{cm} \mathrm{min}^{-1}\right), Z$ is the bed depth of the column $(\mathrm{cm})$, and $N_{0}$ is the adsorption capacity $\left(\mathrm{mg} \mathrm{L}^{-1}\right)$. The experimental data were fitted to this model; the $R^{2}$ parameter indicates the correlation between the experimental points and predicted values [19].

The kinetics of the electrocoagulation removal process were coupled with the fixed-bed adsorption to determine an effective percentage removal. 


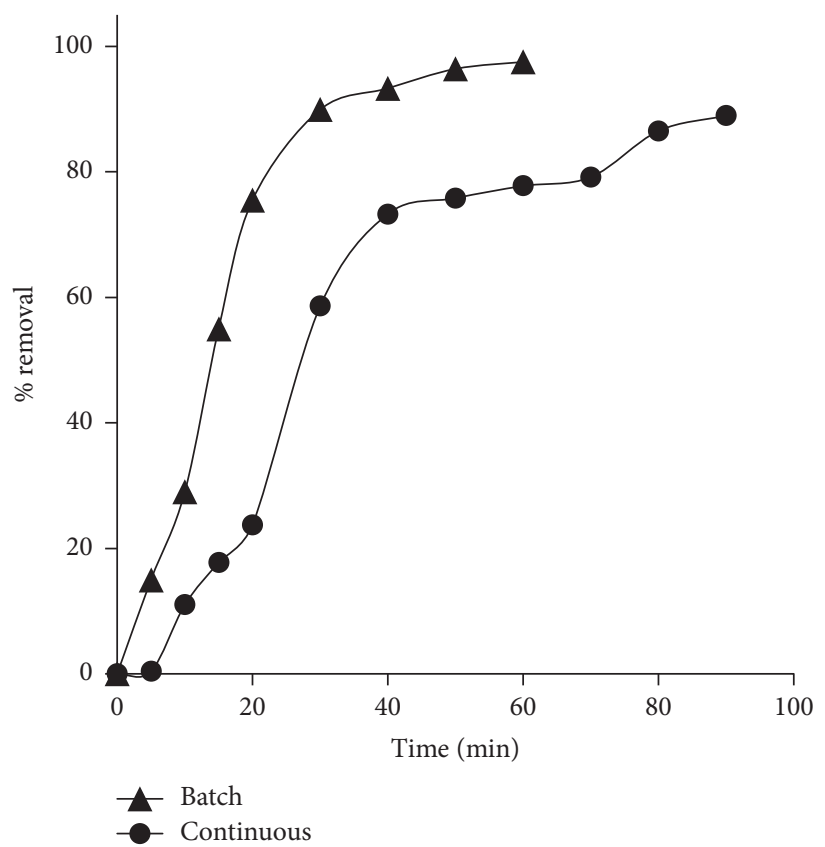

(a)

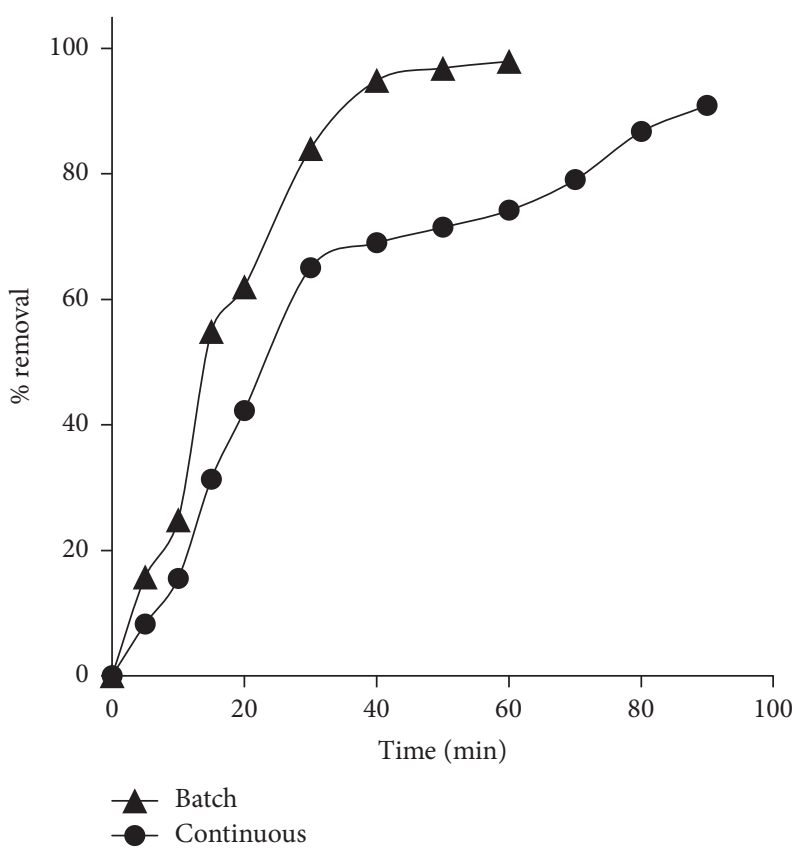

(b)

Figure 2: Comparative performance of the batch and the continuous-mode systems in treating (a) malachite green and (b) Remazol yellow with $100 \mathrm{mg} / \mathrm{L}$ and current input of $35.7 \mathrm{~A} / \mathrm{m}^{2}$.

2.6. Characterizations. For the FT-IR studies, the sludge generated during electrocoagulation before and after dye adsorption was analysed using an FT-IR spectrometer (Nicolet Avatar 360). The samples were dispersed in spectroscopic grade $\mathrm{KBr}$ to record the spectra (sample: $\mathrm{KBr}=1: 100$ ); the IR spectra were recorded over the range of $4000-400 \mathrm{~cm}^{-1}$.

For the SEM observations, the commercial activated carbon and carbonaceous samples, before and after dye adsorption and sewage sludge electrocoagulation, were mounted directly on the holders and observed at 10 and $20 \mathrm{kV}$ using a JEOL $8810 \mathrm{LV}$ microscope. The microanalysis was performed using an EDS system (Oxford).

To determine the point of zero charge, the carbonaceous material $(10 \mathrm{mg})$ was placed in opaque vials with a $0.01 \mathrm{M}$ $\mathrm{NaCl}$ solution that was previously adjusted to a specific $\mathrm{pH}$ value between 1 and 12 (1 unit intervals) using $0.1 \mathrm{M} \mathrm{HCl}$ or $\mathrm{NaOH}$ solutions. After $24 \mathrm{~h}$ of contact, the samples were centrifuged and decanted, and the $\mathrm{pH}$ was determined in the liquid phase (HI $2550 \mathrm{pH} / \mathrm{ORP}$ meter and EC/TDS/NaCl meter HANNA analyser).

Specific surface areas were determined using the $\mathrm{N}_{2}$ BET nitrogen adsorption method with a Micrometrics ${ }^{\circledR}$ Gemini 2360 surface area analyser. The dry and degassed samples were analysed using a multipoint $\mathrm{N}_{2}$ adsorption-desorption method at room temperature.

2.7. Adsorption Batch Experiments. One-hundred milligrams of carbonaceous material and $10 \mathrm{~mL}$ of aliquots of different concentrations of RY or MG (at concentrations of 20,40, $60,80,100$, and $\left.150 \mathrm{mg} \mathrm{L}^{-1}\right)$ were studied over the course of $5 \mathrm{~h}$ in a water bath $(303,313$, and $323 \mathrm{~K})$ using a previously established method [16]. Later, the samples were decanted to separate the phases. All adsorption experiments were performed in duplicate. In addition, dye solutions with varying $\mathrm{pH}$ values $(4,6,8$, and 10$)$ were tested. The $\mathrm{pH}$ of the solution was adjusted using $1 \mathrm{M} \mathrm{HCl}$ and $1 \mathrm{M} \mathrm{NaOH}$. Each mixture was vacuum filtered, and the dye concentrations were determined in the liquid phase. The amount of dye on the corresponding material $q_{e}(\mathrm{mg} / \mathrm{g})$ was calculated using a mass balance relationship: $q_{e}=\left(C_{0}-C_{e}\right) V / W$, where $C_{0}\left(\mathrm{mg} \mathrm{L}^{-1}\right)$ and $C_{e}\left(\mathrm{mg} \mathrm{L}^{-1}\right)$ are the initial and equilibrium liquid-phase concentrations of the dye, respectively; $V(\mathrm{~L})$ is the volume of the solution; and $W(\mathrm{~g})$ is the weight of the corresponding material.

\section{Results and Discussion}

3.1. Batch and Continuous Modes of Operation. The batch mode was found to significantly enhance the efficiency of the electrochemical treatment process in terms of the dye removal, as demonstrated in Figure 2. The maximum dye removal for both dyes using the batch-mode and continuousmode electrocoagulation was achieved at $60 \mathrm{~min}$ and $90 \mathrm{~min}$, respectively.

Notably, a continuous system operates under steady-state conditions with a fixed pollutant concentration and effluent flow rate. In contrast, the dynamic nature of a batch reactor enables studying a range of operating conditions and is more suited to research studies. Continuous systems are better suited for industrial processes with large effluent volumes, whereas batch reactors are suited for laboratory- and pilot plant-scale applications. The continuous mode of operation 


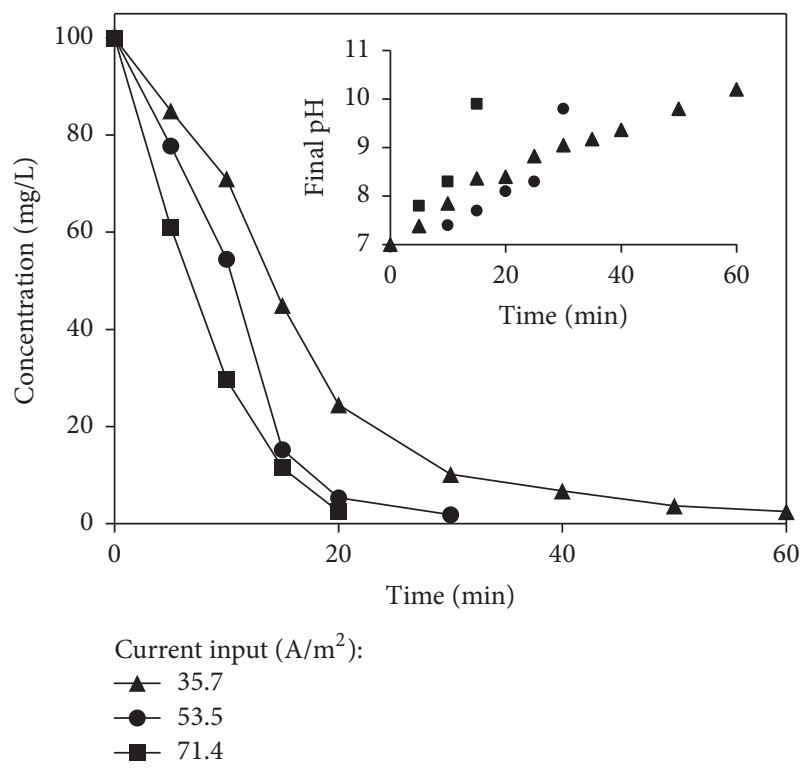

(a)

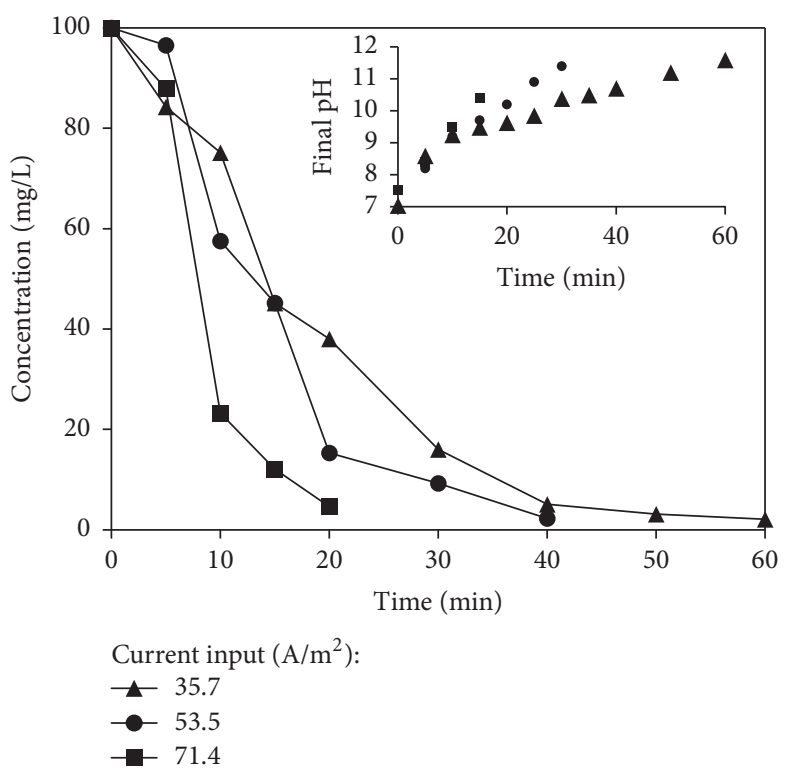

(b)

Figure 3: Effect of current density and final $\mathrm{pH}$ on the (a) Remazol yellow removal and (b) malachite green with $100 \mathrm{mg} / \mathrm{L} . \mathbf{\Lambda}: 35.7 \mathrm{~A} / \mathrm{m}^{2}$, $53.5 \mathrm{~A} / \mathrm{m}^{2}$, and $\mathbf{m :} 71.4 \mathrm{~A} / \mathrm{m}^{2}$.

is preferred due to its better control compared to the batch mode of operation [10]. We studied the removal of reactive blue 21 dye by electrocoagulation using iron electrodes in batch and continuous modes. The results showed that the colour and chemical oxygen demand removal in the batch reactor were higher than those in the continuousflow electrocoagulator because the distribution of electroactive species in the batch reactor was more effective [20]. Moreover, the electrocoagulation process was conducted in both continuous and batch modes and was determined to be an efficient and viable process for achieving a high degree of total petroleum hydrocarbon removal from petroleumcontaminated groundwater [21]. However, on a large scale in the field, the treatment process must be run in continuous mode [10].

\subsection{Operation of the Continuous-Mode Electrocoagulation} Process. To establish a favourable current density value for the continuous mode, electrocoagulation processes were performed. Three values of the current density, 35.7, 53.5, and $71.4 \mathrm{~A} \mathrm{~m}^{-2}$, at a fixed inlet concentration of $C_{0}=100 \mathrm{mg} \mathrm{L}^{-1}$ with $\mathrm{pH}$ values between 5 and 6 were studied.

According to [22], the pollutant removal efficiency decreases with increasing initial dye concentration at a constant current density due to the formation of flocs formed from metal hydroxides that are unable to settle. Therefore, in our case, having a variable current density with a continuous system, it was decided to use an initial concentration of $100 \mathrm{mg} \mathrm{L}^{-1}$ by predicting a residue less than $20 \mathrm{mg} \mathrm{L}^{-1}$ for the coupled sorption process. Residual concentrations of $10 \mathrm{mg} \mathrm{L}^{-1}$ have been reported for sorption processes $[4,23,24]$.
The initial $\mathrm{pH}$ values of these two dyes were nearly neutral. Therefore, chemical modification was not necessary since previous studies [25] have reported that $\mathrm{pH}$ values between 6 and 7 are suitable and it was compatible with Fe electrodes. Importantly, since the tests were continuous, a significant $\mathrm{pH}$ increase was not expected, regardless of whether the water was introduced from a surface water table or was reused; hence, the $\mathrm{pH}$ was expected to remain neutral, and we did not expect to apply acid or base to the treated water [26].

The data for a $60 \mathrm{~min}$ operation are presented in Figure 3.

As shown in Figure 3, the concentration of MG and RY decreased significantly with the increased current density. For both dyes, the time required to reach the plateau region also decreased from $60 \mathrm{~min}$ to less than $20 \mathrm{~min}$ when the current density was increased from 35.7 to $71.4 \mathrm{~A} \mathrm{~m}^{-2}$. Consequently, the number of metallic hydroxides produced increased with electrocoagulation at $71.4 \mathrm{~A} \mathrm{~m}^{-2}$. Therefore, the optimum current density was chosen as $35.7 \mathrm{~A} \mathrm{~m}^{-2}$. This current density was used for further experiments with the continuous-mode system. The current density determines the coagulant dosage within an electrocoagulation process, adjusts the bubble production, and, hence, affects the growth of flocs in both batch and continuous reactors $[9,27]$.

According to Faraday's law (see (1)), as the current density increases, the ion concentrations produced by the electrodes also increase, thereby increasing the flow production and improving the dye removal efficiency [26].

The amount of the electrode that dissolved was theoretically calculated as $1.04,1.56$, and $2.08 \mathrm{~g}$, following Faraday's law, corresponding to current densities of 35.7, 53.5, and $71.4 \mathrm{~A} \mathrm{~m}^{-2}$, respectively. Similar effects of the current density 
on the electrocoagulation process have also been reported for the treatment of other organic and inorganic contaminants, such as textile wastewater [9] and heavy metals from waste fountain solutions (copper, zinc, and nickel) [28].

Furthermore, solar cells were used to supply power as a sustainable and low-cost option for treatment. Photovoltaic modules have a long life and low maintenance cost and can produce high direct currents when exposed to sunlight [29].

The electrolytic reactions during electrocoagulation with Fe electrodes include metal dissolution (anode) and water reduction (cathode). Two mechanisms for the production of metal hydroxides have been proposed [22, 30]. During the process studied herein, the $\mathrm{pH}$ increased from 5.3 to 11 (Figure 3) due to the production of hydroxides. The $\mathrm{OH}^{-}$production from the reaction increased the $\mathrm{pH}$ during electrolysis. Consequently, insoluble $\mathrm{Fe}(\mathrm{OH})_{2}$ precipitates were formed at $\mathrm{pH}>5.5$ and remained in equilibrium with $\mathrm{Fe}^{2+}$ up to a $\mathrm{pH}$ of 9.5 or with monomeric species such as $\mathrm{Fe}(\mathrm{OH})^{+}, \mathrm{Fe}(\mathrm{OH})_{2}$, and $\mathrm{Fe}(\mathrm{OH})_{3}$ at higher $\mathrm{pH}$ values. Once the insoluble flocs of $\mathrm{Fe}(\mathrm{OH})_{3}$ were produced, they could remove the dissolved dyes by surface complexation or electrostatic attraction [31]. The relative stability of the $\mathrm{pH}$ after this process was likely due to the formation of insoluble $\mathrm{Fe}(\mathrm{OH})_{3}$ flocs and other metal hydroxides. The influent $\mathrm{pH}$ is an important parameter that influences the performance of the electrocoagulation process. When the $\mathrm{pH}$ of the dye solutions was between 5.5 and 8.5, maximum removal was achieved. As the initial $\mathrm{pH}$ value was approximately 6.5 for both dye solutions, additional chemicals were not required to change the initial $\mathrm{pH}$ values.

The formed $\mathrm{Fe}(\mathrm{OH})_{n(s)}$ can remove dye molecules by surface complexation or electrostatic attraction. During surface complexation, it was assumed that the pollutant could act as a ligand to bind hydrous iron moieties using precipitation and adsorption mechanisms $[22,30]$.

Additionally, the removal mechanism of the azo dye may have actually complexed with the iron hydroxide-forming ionic bonds as follows [18]:

$$
\begin{aligned}
& \mathrm{R}-\mathrm{SO}_{3} \mathrm{Na}+(\mathrm{OH})_{3}\left(\mathrm{H}_{2} \mathrm{O}\right) \mathrm{Fe} \\
& \quad \longrightarrow \mathrm{R}-\mathrm{SO}_{3}-(\mathrm{OH})_{2} \mathrm{H}_{2} \mathrm{OFe}+\mathrm{Na}^{+}+\mathrm{OH}^{-}
\end{aligned}
$$

Figure 4 presents plots of the first-order kinetic model fitted to the experimental data. Figure 4 reveals a reasonably good fit for the first-order kinetic model for both dyes $\left(r^{2}>\right.$ 0.93). Based on the linear regression equation fitted to the experimental data, the first-order removal rate constants for MG and RY were 0.0035 and $0.0034 \mathrm{~min}^{-1}$, respectively.

Similar results were found during the removal of phosphate from landscape water using an electrocoagulation process with aluminium electrodes powered directly by photovoltaic solar modules; the first model was adequately applied to the experimental data [29]. Based on these results, we confirmed that electrocoagulation has the ability to simultaneously remove cationic and anionic dyes from aqueous solutions.

3.3. Batch Adsorption Experiments. Adsorption equilibrium experiments were performed to describe the dye adsorption

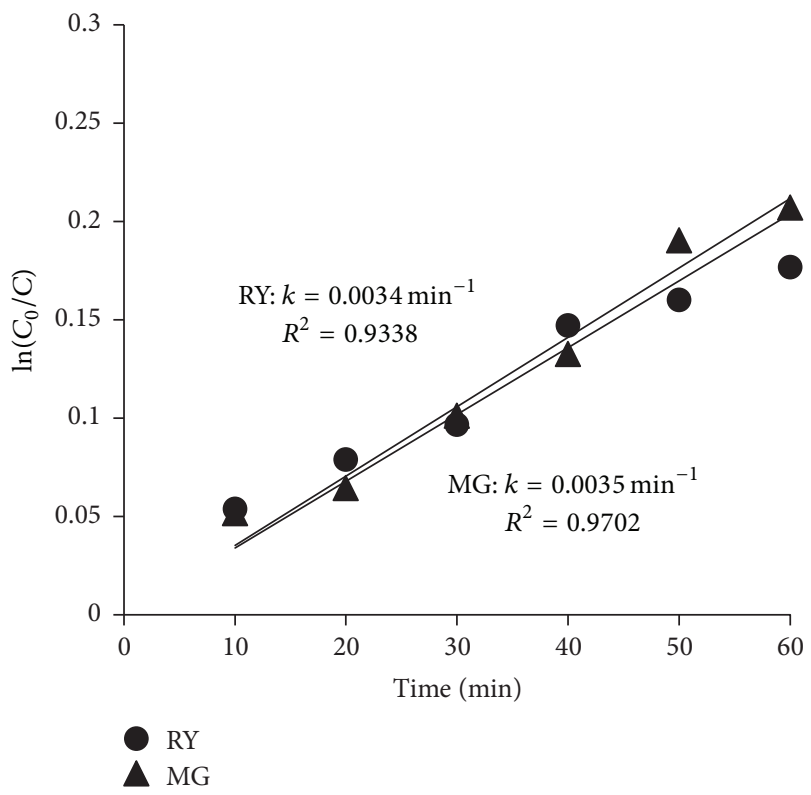

FIGURE 4: Plot of the first-order equation for (electrocoagulation) removal kinetics of malachite green (MG) and Remazol yellow (RY) in aqueous solution.

behaviour of the carbonaceous material. Two models, the Langmuir and Freundlich isotherms, were employed to analyse MG and RY adsorption data, and the respective constants of each model were estimated using nonlinear regression analysis [32].

Langmuir:

$$
q_{e}=\frac{q_{o} b C_{e}}{1+b C_{e}}
$$

Freundlich:

$$
q_{e}=K_{F} C_{e}^{1 / n}
$$

where $C_{e}$ is the dye concentration at equilibrium $\left(\mathrm{mg} \mathrm{L}^{-1}\right), q_{e}$ is the adsorption capacity at equilibrium $\left(\mathrm{mg} \mathrm{g}^{-1}\right), q_{o \max }$ is the maximum adsorption capacity $\left(\mathrm{mg} \mathrm{g}^{-1}\right), b$ is the adsorption energy constant $\left(\mathrm{L} \mathrm{mg}^{-1}\right), K_{F}$ is the Freundlich adsorbent capacity, and $1 / n$ is the heterogeneity factor. Table 1 shows the parameters obtained after applying these models to the experimental data, and Figure 5 shows the experimental data and Langmuir model. The correlation coefficient for the Langmuir isotherm was greater than that for the Freundlich isotherm for RY adsorption, while the opposite behaviour was observed for MG adsorption. The Langmuir model assumes monolayer adsorption onto a surface containing a finite number of adsorption sites via a uniform adsorption mechanism without transmigration of the adsorbate along the surface plane. The Freundlich equation is based on adsorption onto a heterogeneous surface [33].

In the MG adsorption case, the experimental data were adjusted to both models with similar correlation values $\left(R^{2}=\right.$ 
TABLE 1: Adsorption isotherm parameters of Remazol yellow and malachite green by carbonaceous material.

\begin{tabular}{lcccccc}
\hline & \multicolumn{3}{c}{ Adsorption isotherms } & \multicolumn{2}{c}{ Freundlich } \\
Dye & Langmuir & \multicolumn{2}{c}{$K_{F}$} & $1 / n$ & $r^{2}$ \\
& $\begin{array}{c}q_{\max } \\
(\mathrm{mg} / \mathrm{g})\end{array}$ & $b$ & $r^{2}$ & 0.5593 & 0.55 & 0.9832 \\
Remazol yellow & 11.69 & 0.015 & 0.9926 & 6.16 & 0.45 & 0.9745 \\
\hline
\end{tabular}

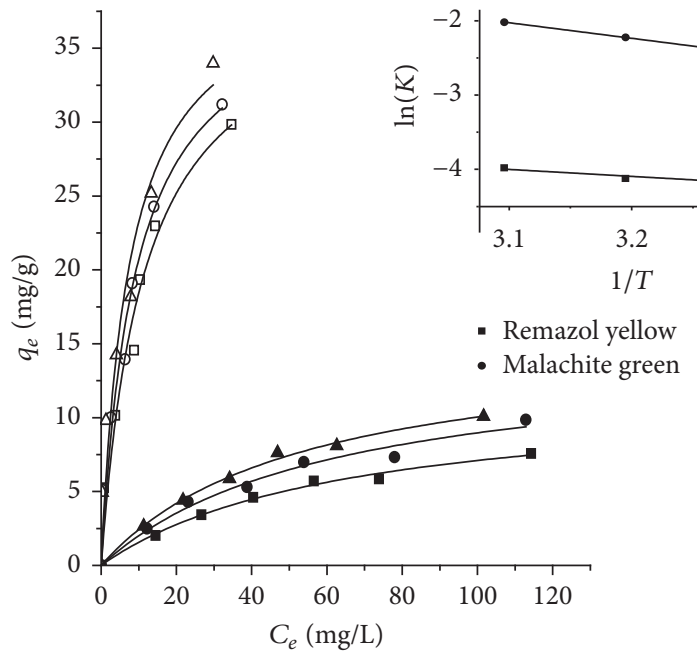

\begin{tabular}{ll} 
Malachite green & Remazol yellow \\
口 $30^{\circ} \mathrm{C}$ & - $30^{\circ} \mathrm{C}$ \\
$-40^{\circ} \mathrm{C}$ & $-40^{\circ} \mathrm{C}$ \\
$\triangle 50^{\circ} \mathrm{C}$ & $\Delta 50^{\circ} \mathrm{C}$ \\
\hline$\quad$ Langmuir model &
\end{tabular}

FIGURE 5: Langmuir model and Van't Hoff plot for the adsorption of the Remazol yellow and malachite green onto carbonaceous material.

0.97). The Langmuir model is based on the assumption of a homogeneous adsorbing surface and the independence of the adsorption sites. However, carbonaceous material is a heterogeneous product of sewage sludge carbonization, and the chemistry composition of the material used herein was heterogeneous based on the EDS analyses.

The maximum adsorption capacities of $\mathrm{RY}\left(q_{e}=\right.$ $\left.11.69 \mathrm{mg} \mathrm{g}^{-1}\right)$ and MG $\left(q_{e}=39.76 \mathrm{mg} \mathrm{g}^{-1}\right)$ on the carbonaceous material were determined. A similar result was found for the adsorption of RY onto the carbonaceous material prepared from sewage sludge $\left(12.72 \mathrm{mg} \mathrm{g}^{-1}\right)$ [16], while the adsorption of MG onto the carbonaceous material was superior to that on the commercial activated carbon in the batch system [40].

The $\mathrm{pH}$ of a solution is an important parameter during a sorption process. The initial $\mathrm{pH}$ was inversely related to the adsorption capacity at equilibrium for both dyes. When the initial $\mathrm{pH}$ of the dye solution increased from 4 to 12 for $\mathrm{RY}$, the adsorption capacity decreased; with an increase in the $\mathrm{pH}$, the adsorption capacity of MG increased (figure not shown). The $\mathrm{pH}$ values substantially affected the availability
TABLE 2: Thermodynamic parameters for the adsorption of Remazol yellow and malachite green by carbonaceous material.

\begin{tabular}{lccccc}
\hline Dye & \multirow{2}{*}{$\Delta H\left(\mathrm{~kJ} \cdot \mathrm{mol}^{-1}\right)$} & $\Delta S\left(\mathrm{~kJ} \cdot \mathrm{mol}^{-1}\right)$ & \multicolumn{4}{c}{$\Delta G\left(\mathrm{~kJ} \cdot \mathrm{mol}^{-1}\right)$} \\
& & & $303 \mathrm{~K}$ & $313 \mathrm{~K}$ & $323 \mathrm{~K}$ \\
\hline Remazol yellow & 7.76 & -0.009 & 10.48 & 10.57 & 10.66 \\
Malachite green & 17.53 & 0.037 & 6.31 & 5.94 & 5.57 \\
\hline
\end{tabular}

of dye to interact with the adsorbent surface in solution [24]; the dyes could be positively or negatively charged to favour the selective adsorption using basic and acid materials, respectively.

To estimate the effect of the temperature on the dye adsorption onto the carbonaceous material, three basic thermodynamic parameters, the enthalpy $(\Delta H)$, entropy $(\Delta S)$, and Gibbs free energy $(\Delta G)$, were calculated using a relationship between the equilibrium constant $\left(K_{L}\right)$ and temperature $(T)$, which is expressed using the Van't Hoff equation as follows [41, 42]:

$$
\begin{aligned}
\ln K_{L} & =\frac{\Delta S}{R}-\left(\frac{\Delta H}{R}\right)\left(\frac{1}{T}\right) \\
\Delta G & =\Delta H-T \Delta S,
\end{aligned}
$$

where $K_{L}, R$, and $T$ are the Langmuir equilibrium constant, the universal gas constant $\left(8.314 \mathrm{~J} \cdot \mathrm{mol}^{-1} \mathrm{~K}^{-1}\right)$, and the absolute temperature in $\mathrm{K}$, respectively.

The values of the thermodynamic parameters, enthalpy $(\Delta H)$, Gibbs energy change $(\Delta G)$, and entropy change $(\Delta S)$, of the adsorption process for RY and MG are shown in Figure 5 and Table 2. The positive value for the Gibbs energy change $(\Delta G)$ shows that the adsorption process was not spontaneous [42]. The positive value of $\Delta H$ indicates the endothermic nature of the adsorption process. The positive values of $\Delta S$ for MG indicate that the randomness at the solid-liquid interface during the adsorption process increased and reflect the affinity of the adsorbent material for MG. In contrast, for RY, the negative standard entropy change $(\Delta S)$ suggests that the randomness at the solid/solution interface decreased during adsorption. Similar behaviour was observed during the adsorption of three Bezathren dyes using sodic bentonite [43].

3.4. Fixed-Bed Adsorption Experiments. Figure 6 shows the fit of the experimental results to the Bohart-Adams model, and Table 3 summarizes the parameters calculated for the adsorption of MG and RY by the commercial activated carbon and carbonaceous material. 


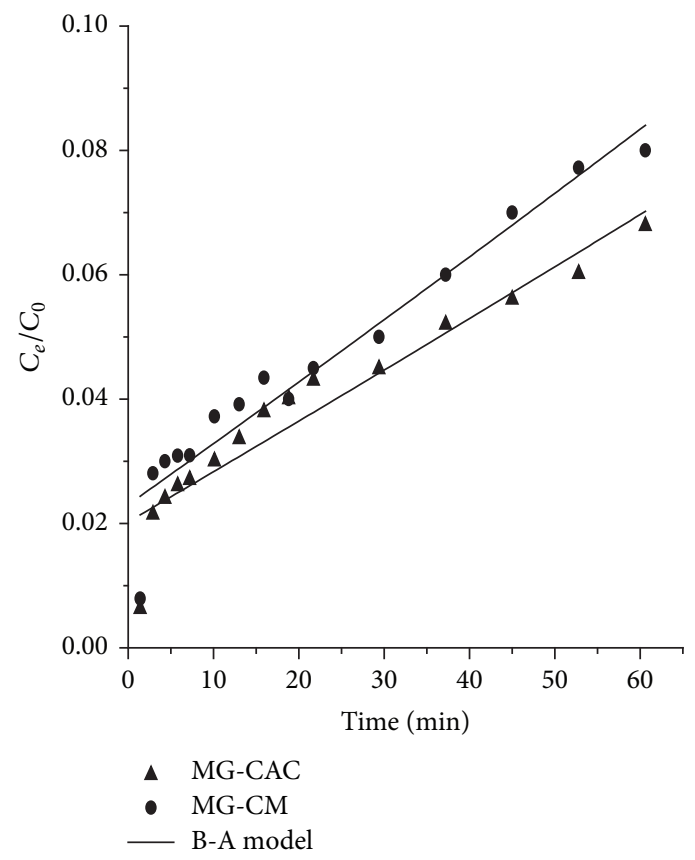

(a)

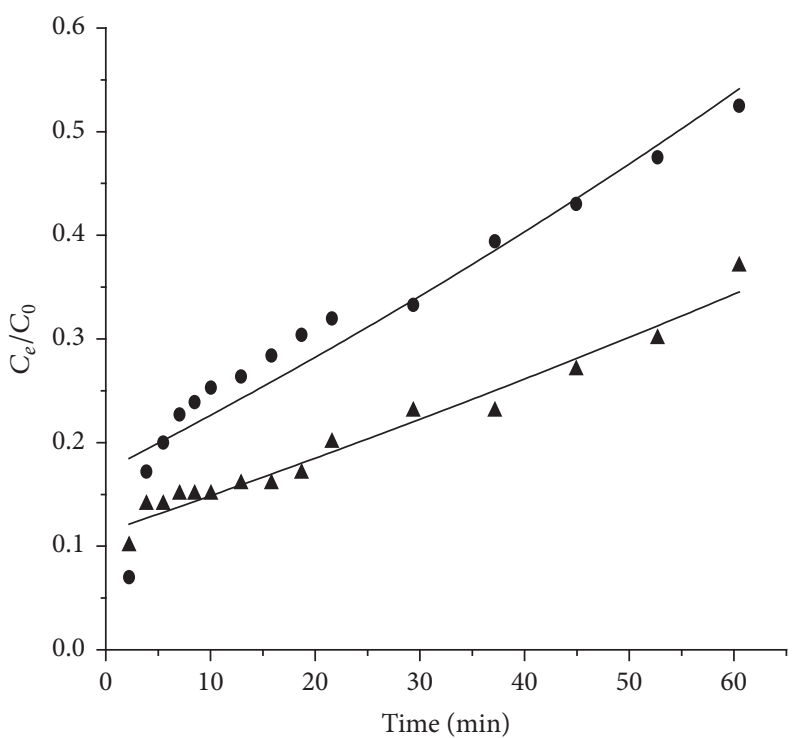

$\triangle$ RY-CAC

- RY-CM

- B-A model

(b)

FIGURE 6: Comparison of fitted curves and experimental data using the Bohart-Adams model for the adsorption of (a) malachite green and (b) Remazol yellow using CAC and CM $(h=17 \mathrm{~cm})$.

The removal of RY using carbonaceous material from pyrolyzed sewage sludge treated with $10 \% \mathrm{HCl}$ was evaluated using adsorption equilibria. The results indicated that the main mechanism involved in the adsorption of the dye was chemisorption on a heterogeneous material [16]. However, MG removal has not been reported for batch adsorption.

For both materials, the results revealed that the maximum adsorption capacities were higher for the cationic dye (MG) than for the anionic dye (RY), even though the initial concentration was higher for the first dye. The treatment of the carbonaceous material with $10 \%$ HCL likely played a major role in the removal of the cationic dye. For the MG adsorption, the carbonaceous material breakthrough curve showed similar behaviour to that obtained for the CAC breakthrough curve (Figure 6(a)).

The adsorption rate was faster for RY than for MG. As seen in Table 3, the $R^{2}$ values were higher than 0.90 for both dyes and adsorbents. Thus, this model showed good agreement between the predicted and experimental data up to $C_{e} / C_{0}=0.5$ for all experiments. This trend can be explained by the prevalence of external mass transfer during the initial adsorption in the column [44].

A comparison of the two adsorbents (Table 3) indicated that the values of the maximum adsorption capacities for the CAC system were higher than those for the carbonaceous material system.

Usually, the breakthrough point is defined as the time when the effluent concentration $\left(C_{e}\right)$ reaches a percentage of the influent concentration $\left(C_{0}\right)$ that is considered unacceptable, for example, $10 \%\left(C_{e} / C_{0}=0.1\right)$. For the anionic dye, the breakthrough point was less than $5 \mathrm{~min}$, while for the cationic
TABLE 3: Bohart-Adams-fitting parameters for the adsorption of malachite green and Remazol yellow using commercial activated carbon and carbonaceous material.

\begin{tabular}{lcccc}
\hline & \multicolumn{2}{c}{$\begin{array}{c}\text { Malachite } \\
\text { green }\end{array}$} & \multicolumn{2}{c}{$\begin{array}{c}\text { Remazol } \\
\text { yelow }\end{array}$} \\
& CAC & CM & CAC & CM \\
\hline$C_{0}\left(\mathrm{mg} \mathrm{L}^{-1}\right)$ & 10.34 & 10.34 & 6.10 & 6.10 \\
$k_{\mathrm{BA}}\left(10^{-5}\right)$ & 7.77 & 9.45 & 56.47 & 84.93 \\
$\left(\mathrm{Lmg}^{-1} \mathrm{~min}^{-1}\right)$ & 7796.32 & 6396.67 & 971.27 & 602.42 \\
$N_{o}\left(\mathrm{mg} \mathrm{L}^{-1}\right)$ & 0.9057 & 0.9279 & 0.9630 & 0.9019 \\
$R^{2}$ & & & & \\
\hline
\end{tabular}

dye it was more than $60 \mathrm{~min}$. These results indicate that both of the adsorbent materials exhibited a high affinity for the MG dye.

Figure 7 compares the removal efficiencies of MG and RY by electrocoagulation as a single treatment method and electrocoagulation-adsorption using the $\mathrm{CAC}$ and carbonaceous material; this figure shows the effectiveness of the coupled treatment during dye removal.

The removal increased significantly, and the increase in the removal demonstrated the feasibility and synergic effect of the coupled process. The dye removal efficiencies ranged from $96 \%$ to $99 \%$; the high dye removal efficiency was due to the combined electrocoagulation and adsorption on the CAC and its high surface area. Furthermore, both adsorbents showed a greater affinity for the cationic dye (MG) than for the anionic dye (RY). These results describe the electrocoagulation-adsorption performance in a continuous 
TABLE 4: Comparison of dye removal performances of various treatment technologies.

\begin{tabular}{|c|c|c|c|c|c|}
\hline Treatment method & Dye & Material & $\begin{array}{c}\text { Initial } \\
\text { concentration }\end{array}$ & Removal efficiency $/ q_{e}$ & Reference \\
\hline Biological & MG & $\begin{array}{l}\text { T. versicolor laccase-basic } \\
\text { exchange resin D201 }\end{array}$ & $50 \mathrm{mg} \mathrm{L}^{-1}$ & $35-40 \%$ & {$[34]$} \\
\hline \multirow{2}{*}{ Catalysis } & MG & $\mathrm{ZnS}, \mathrm{ZnS}: \mathrm{Fe}$ & $15 \mathrm{mg} \mathrm{L}^{-1}$ & $98.3 / 99.0 \%$ & [5] \\
\hline & RY & $\mathrm{ClO}_{2}$ catalytic oxidation & $200 \mathrm{mg} \mathrm{L}^{-1}$ & $94.03 \%$ & [35] \\
\hline Electrolysis & MG & BDD electrodes & $20 \mathrm{mg} \mathrm{L}^{-1}$ & $91 \%$ & {$[36]$} \\
\hline \multirow{7}{*}{ Adsorption } & MG & $\begin{array}{l}\text { Microorganisms based } \\
\text { compost }\end{array}$ & $50-1000 \mathrm{mg} \mathrm{L}^{-1}$ & $96.8 \% / 136.6 \mathrm{mg} \mathrm{g}^{-1}$ & {$[37]$} \\
\hline & MG & Shell-treated Zea mays & $10-200 \mathrm{Mg} \mathrm{L}^{-1}$ & $\mathrm{NA} / 81.5 \mathrm{mg} \mathrm{g}^{-1}$ & {$[38]$} \\
\hline & $\mathrm{RY}$ & $\mathrm{Fe}-\mathrm{Ni}$ nanoscale oxides & $100 \mathrm{mg} \mathrm{L}^{-1}$ & $83 \% / 157 \mathrm{mg} \mathrm{g}^{-1}$ & [39] \\
\hline & $\mathrm{RY}$ & $\mathrm{Fe}-\mathrm{Cu}$ nanoscale oxides & $100 \mathrm{mg} \mathrm{L}^{-1}$ & $70 \% / 117.6 \mathrm{mg} \mathrm{g}^{-1}$ & [39] \\
\hline & $\mathrm{RY}$ & Montmorillonite KSF & $100 \mathrm{mg} \mathrm{L}^{-1}$ & $\mathrm{NA} / 8.62 \mathrm{mg} \mathrm{g}^{-1}$ & {$[6]$} \\
\hline & RY & $\begin{array}{l}\text { Carbonaceous material-1\% } \\
\mathrm{HCl}\end{array}$ & $100 \mathrm{mg} \mathrm{L}^{-1}$ & $\mathrm{NA} / 12.72 \mathrm{mg} \mathrm{g}^{-1}$ & [16] \\
\hline & RY & Apple pulp- $\mathrm{TiO}_{2}$ & $10 \mathrm{mg} \mathrm{L}^{-1}$ & $86.97 \% / \mathrm{NA}$ & [23] \\
\hline \multirow{4}{*}{$\begin{array}{l}\text { Electrocoagulation- } \\
\text { adsorption }\end{array}$} & MG & $\begin{array}{l}\text { Fe electrodes/commercial } \\
\text { activated carbon }\end{array}$ & $100 \mathrm{mg} \mathrm{L}^{-1}$ & $99.29 \% / 7796.32 \mathrm{mg} \mathrm{L}^{-1}$ & This work \\
\hline & MG & $\begin{array}{l}\text { Fe electrodes/carbonaceous } \\
\text { material }\end{array}$ & $100 \mathrm{mg} \mathrm{L}^{-1}$ & $99.17 \% / 6396.67 \mathrm{mg} \mathrm{L}^{-1}$ & This work \\
\hline & RY & $\begin{array}{l}\text { Fe electrodes/commercial } \\
\text { activated carbon }\end{array}$ & $100 \mathrm{mg} \mathrm{L}^{-1}$ & $99.77 \% / 971.27 \mathrm{mg} \mathrm{L}^{-1}$ & This work \\
\hline & $\mathrm{RY}$ & $\begin{array}{l}\text { Fe electrodes/carbonaceous } \\
\text { material }\end{array}$ & $100 \mathrm{mg} \mathrm{L}^{-1}$ & $96.79 \% / 602.42 \mathrm{mg} \mathrm{L}^{-1}$ & This work \\
\hline
\end{tabular}

NA: not available.

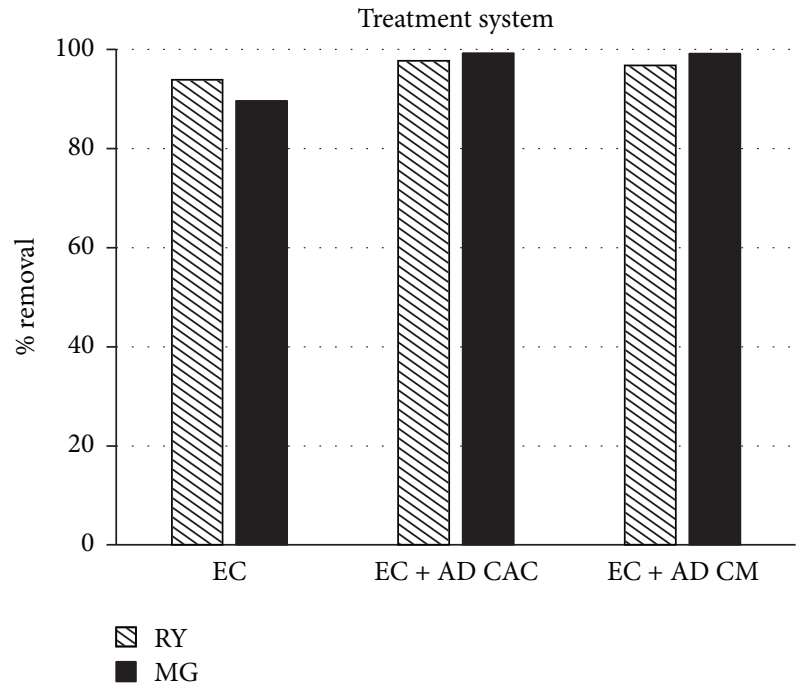

FIgURE 7: Malachite green and Remazol yellow removal efficiencies with electrocoagulation and electrocoagulation-adsorption CAC and electrocoagulation-adsorption CM.

system to explore the possibility of using the system for treating real textile effluents.

Previous studies have compared electrocoagulationadsorption to other conventional and advanced methods (Table 4). Abundant information is available regarding MG and RY adsorption but not MG and RY electrocoagulation.
It is difficult to compare the results of this work with those from the literature because the dye removal efficiency was determined under different experimental conditions and was dependent on the type of treatment, initial dye concentration, electrode type, and chemical composition of the adsorbent. Notably, in Table 4, the electrocoagulationadsorption resulted in a higher removal efficiency compared to the other treatment methods. The carbonaceous material used in this study shows relatively good adsorption capacities compared with CAC.

3.5. Characterization. The SEM image of the solid sludge precipitates (the product of RY electrocoagulation) is presented in Figure 8(a). This SEM image shows continuous flake-shaped aggregates with diameters of $10-100 \mu \mathrm{m}$. The elemental composition of the MG and RY sludge precipitate samples (Table 5) exhibited carbon $(\mathrm{C})$, oxygen $(\mathrm{O})$, and iron $(\mathrm{Fe})$. The chemical composition of the sewage shows that the quantity of iron notably increased $(>40.51 \%)$ when the samples were treated with electrocoagulation. The presence of silicon $(\mathrm{Si})$ was attributed to the glass slit used for the EDS analysis of the sample.

Figure $8(\mathrm{~b})$ shows the morphology of the activated carbon; a porous structure can be observed, and Figure 8(c) shows the morphology of the carbonaceous material, which is similar to the morphology reported elsewhere [45].

The chemical compositions of the CAC and carbonaceous material before and after MG and RY adsorption are presented in Table 3. The amount of carbon (C) in the adsorbent 


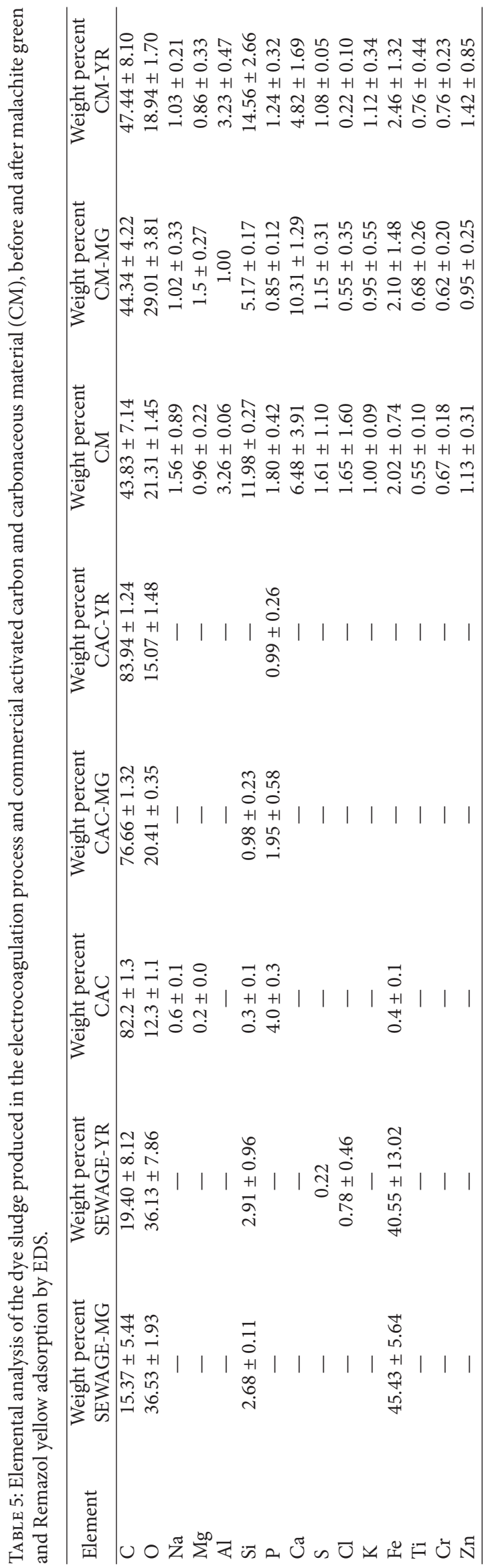




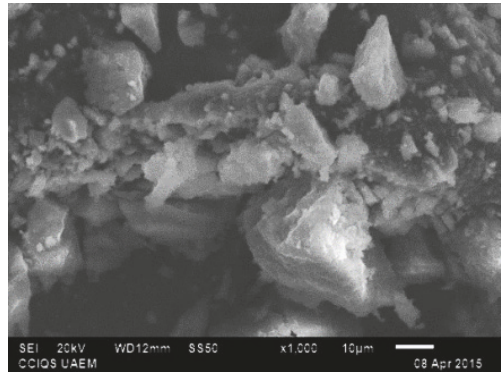

(a)

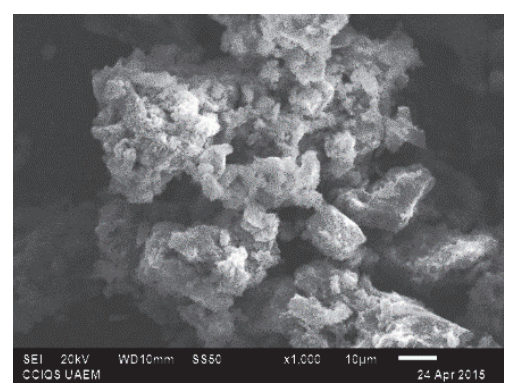

(b)

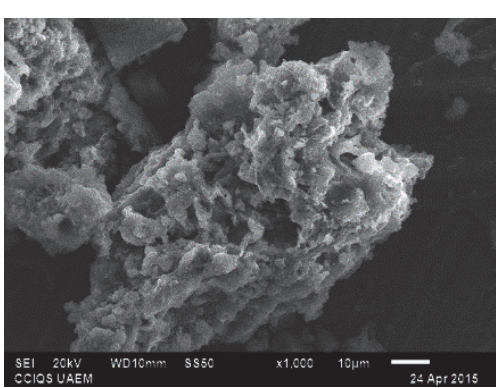

(c)

FIGURE 8: SEM image of the (a) sludge produced in the Remazol yellow-EC process and materials: (b) CAC and (c) CM before adsorption.

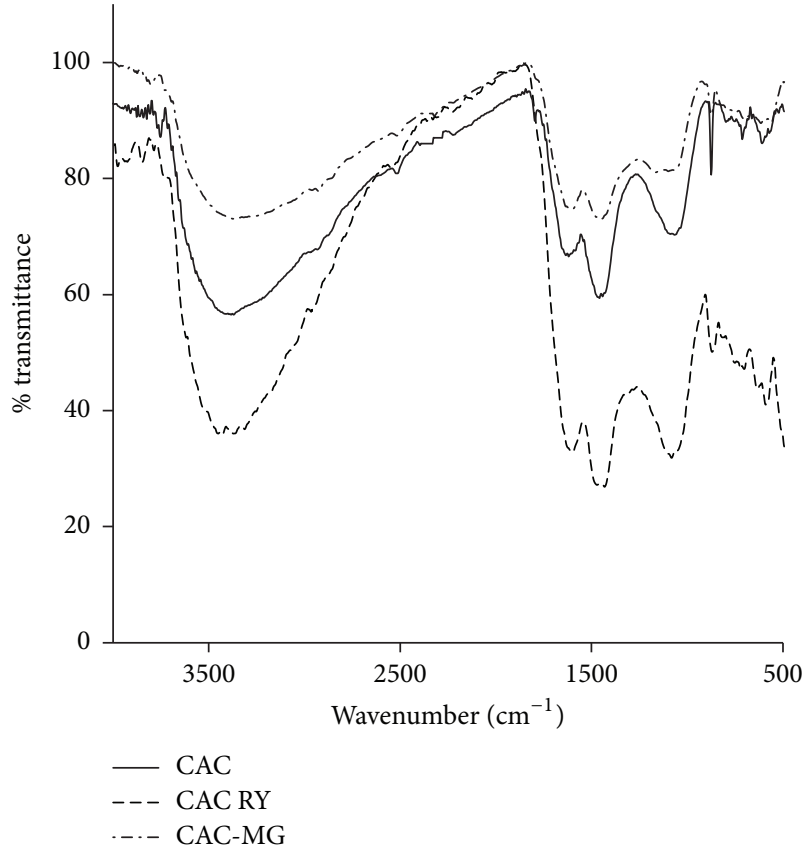

(a)

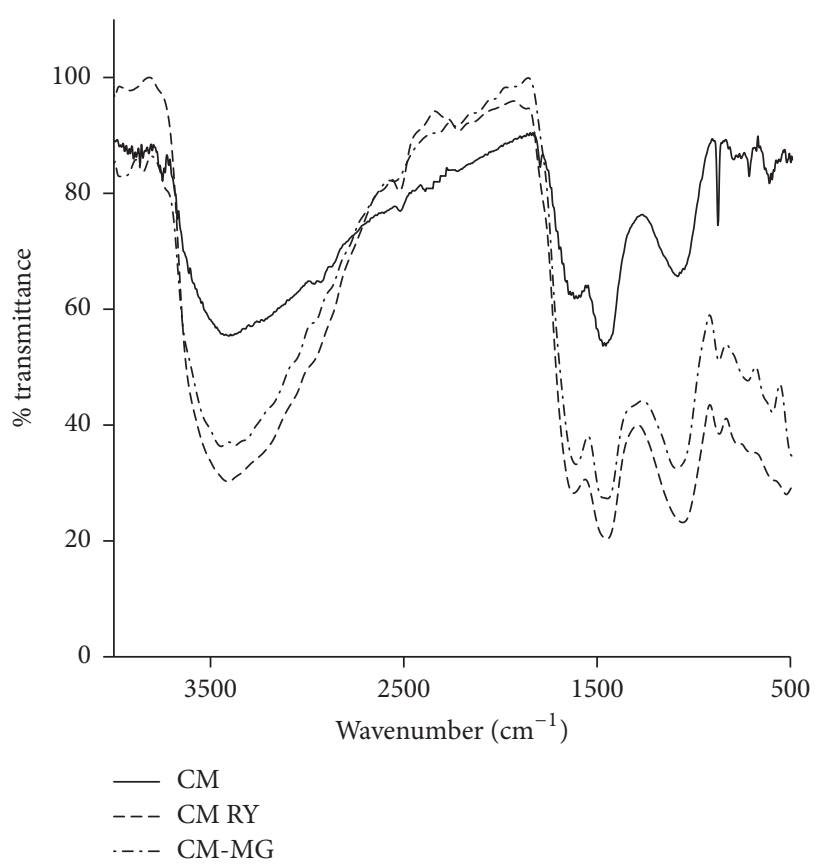

(b)

FIGURE 9: FT-IR characterization of (a) CAC and (b) CM before and after malachite green and Remazol yellow adsorption.

increased when the samples were in contact with the dye solution, which indicated that dye adsorption occurred on the materials.

The point of zero charge of the carbonaceous material was 7.1, and the FT-IR spectra of the MG and RY sludge (figure not shown) presented a broad and intense band at $3317 \mathrm{~cm}^{-1}$ that was attributed to the stretching vibrations of $-\mathrm{OH}$. The variable band at $1630 \mathrm{~cm}^{-1}$ was attributed to the stretching vibration of the $\mathrm{C}=\mathrm{C}$ and $\mathrm{C}=\mathrm{N}$ aromatic groups. The bands at $1369 \mathrm{~cm}^{-1}$ indicated the presence of $\mathrm{CH}_{2}$, and the bands in the 1600 to $1000 \mathrm{~cm}^{-1}$ region corresponded to the $\mathrm{C}-\mathrm{C}$ and $\mathrm{C}-\mathrm{N}$ groups [46]. Similar results have been reported elsewhere [39].

The FT-IR spectra of the carbonaceous material and CAC before and after dye adsorption at $4000-400 \mathrm{~cm}^{-1}$ are presented in Figure 9.
Bands appearing at $3367,2908,1620,1458,1057$, and $876 \mathrm{~cm}^{-1}$ in Figure 9(a) were assigned to $\mathrm{OH}$ stretching, $\mathrm{C}-\mathrm{H}$ stretching in the alkane, $\mathrm{COO}^{-}$anion stretching, $\mathrm{OH}$ bending, C-O stretching in the ester or ether, and $\mathrm{N}-\mathrm{H}$ deformation in the amines, respectively. Of these groups, the carboxylic acid and hydroxyl groups played a major role in the dye removal. Figure 9 (b) shows a large number of bands, indicating the complex nature of the adsorbent carbonaceous material. The bands appearing at 3402, 2974, 1597, 1458, 1080 , and $876 \mathrm{~cm}^{-1}$ were attributed to the presence of $\mathrm{OH}$ groups, $\mathrm{C}-\mathrm{H}$ stretching in the alkanes, $\mathrm{C}=\mathrm{O}$ stretching in the carboxylate groups, and $\mathrm{C}-\mathrm{O}-\mathrm{H}$ stretching. The bands below $1200 \mathrm{~cm}^{-1}$ were considered to be the fingerprint region. The MG- and RY-loaded adsorbents showed either a shift or reduction in most adsorption bands, suggesting that the functional groups played an important role in adsorption. 
The zero charge point of a carbonaceous material is determined when the $\mathrm{pH}_{\mathrm{eq}}$ is equal or quite similar to $\mathrm{pH}_{\text {initial }}$. The zero charge point obtained in this study (7.0) is of the same order of magnitude as the value found by MárquezMendoza et al. [47]; thus, the zero charge point appears to be dependent on the origin of the material.

The BET specific surface areas of the adsorbents were 1471.22 and $100.79 \mathrm{~m}^{2} \mathrm{~g}^{-1}$, and the total pore volumes were 0.7278 and $0.1983 \mathrm{~cm}^{3} \mathrm{~g}^{-1}$ for the CAC and carbonaceous material, respectively. The BET specific surface area may have been responsible for the adsorption behaviour of the materials.

\section{Conclusions}

During electrocoagulation, the removal efficiency achieved in the batch system was higher than that achieved in the continuous electrochemical process. The continuous electrocoagulation-adsorption processes were more efficient for dye removal than electrocoagulation alone. The cationic and anionic dye removal efficiencies achieved during adsorption with the CAC and carbonaceous material were very similar at $96-98 \%$.

The thermodynamic parameters $\Delta G, \Delta H$, and $\Delta S$ indicated that the adsorption process was spontaneous and endothermic. The SEM-EDS and FT-IR analyses of the sludge produced during electrocoagulation and of the adsorbent after adsorption revealed that carbon, oxygen, and the elemental components of the dye were the main byproducts formed after electrocoagulation and adsorption. The chemical composition of the sewage indicated that the quantity of iron notably increased when the samples were treated with electrocoagulation. Thus, the results presented in this work indicate that a continuous electrocoagulation-adsorption process can effectively remove cationic and anionic dyes from water.

\section{Conflicts of Interest}

The authors declare that they have no conflicts of interest.

\section{Acknowledgments}

The authors acknowledge financial support from the CONACYT scholarship (Grant no. 306269) for Josué Alonso Castañeda Díaz and Universidad Autónoma del Estado de México, Project 3688/2014/CIB.

\section{References}

[1] A. Blanco-Flores, A. Colín-Cruz, E. Gutiérrez-Segura et al., "Efficient removal of crystal violet dye from aqueous solutions by vitreous tuff mineral," Environmental Technology, vol. 35, no. 12, pp. 1508-1519, 2014.

[2] E. Brillas and C. A. Martínez-Huitle, "Decontamination of wastewaters containing synthetic organic dyes by electrochemical methods. An updated review," Applied Catalysis B: Environmental, vol. 166-167, pp. 603-643, 2015.
[3] D. Podstawczyk, A. Witek-Krowiak, K. Chojnacka, and Z. Sadowski, "Biosorption of malachite green by eggshells: mechanism identification and process optimization," Bioresource Technology, vol. 160, pp. 161-165, 2014.

[4] M. Ghaedi, E. Shojaeipour, A. M. Ghaedi, and R. Sahraei, "Isotherm and kinetics study of malachite green adsorption onto copper nanowires loaded on activated carbon: artificial neural network modeling and genetic algorithm optimization," Spectrochimica Acta Part A: Molecular and Biomolecular Spectroscopy, vol. 142, pp. 135-149, 2015.

[5] H. R. Rajabi, O. Khani, M. Shamsipur, and V. Vatanpour, "Highperformance pure and $\mathrm{Fe}^{3+}$-ion doped $\mathrm{ZnS}$ quantum dots as green nanophotocatalysts for the removal of malachite green under UV-light irradiation," Journal of Hazardous Materials, vol. 250-251, pp. 370-378, 2013.

[6] A. P. DíazGómez-Treviño, V. Martínez-Miranda, and M. Solache-Ríos, "Removal of remazol yellow from aqueous solutions by unmodified and stabilized iron modified clay," Applied Clay Science, vol. 80-81, pp. 219-225, 2013.

[7] M. T. Yagub, T. K. Sen, S. Afroze, and H. M. Ang, "Dye and its removal from aqueous solution by adsorption: a review," Advances in Colloid and Interface Science, vol. 209, pp. 172-184, 2014.

[8] V. K. Gupta, R. Kumar, A. Nayak, T. A. Saleh, and M. A. Barakat, "Adsorptive removal of dyes from aqueous solution onto carbon nanotubes: a review," Advances in Colloid and Interface Science, vol. 193-194, pp. 24-34, 2013.

[9] B. Merzouk, B. Gourich, A. Sekki, K. Madani, Ch. Vial, and M. Barkaoui, "Studies on the decolorization of textile dye wastewater by continuous electrocoagulation process," Chemical Engineering Journal, vol. 149, no. 1-3, pp. 207-214, 2009.

[10] V. Khandegar and A. K. Saroha, "Electrocoagulation for the treatment of textile industry effluent-a review," Journal of Environmental Management, vol. 128, pp. 949-963, 2013.

[11] E. Gutiérrez-Segura, M. Solache-Ríos, A. Colín-Cruz, and C. Fall, "Comparison of cadmium adsorption by inorganic adsorbents in column systems," Water, Air, and Soil Pollution, vol. 225, no. 6, pp. 1943-1956, 2014.

[12] E. Yuksel, E. Gurbulak, and M. Eyvaz, "Decolorization of a reactive dye solution and treatment of a textile wastewater by electrocoagulation and chemical coagulation: Techno-economic comparison," Environmental Progress and Sustainable Energy, vol. 31, no. 4, pp. 524-535, 2012.

[13] V. K. Gupta and Suhas, "Application of low-cost adsorbents for dye removal-a review," Journal of Environmental Management, vol. 90, no. 8, pp. 2313-2342, 2009.

[14] I. Ali, M. Asim, and T. A. Khan, "Low cost adsorbents for the removal of organic pollutants from wastewater," Journal of Environmental Management, vol. 113, pp. 170-183, 2012.

[15] N. Abidi, E. Errais, J. Duplay et al., "Treatment of dye-containing effluent by natural clay," Journal of Cleaner Production, vol. 86, pp. 432-440, 2015.

[16] J. Torres-Pérez, M. Solache-Ríos, and A. Colín-Cruz, "Sorption and desorption of dye remazol yellow onto a Mexican surfactant-modified clinoptilolite-rich tuff and a carbonaceous material from pyrolysis of sewage sludge," Water, Air, and Soil Pollution, vol. 187, no. 1-4, pp. 303-313, 2008.

[17] G. Tchobanoglous, F. L. Burton, and H. D. Stensel, Wasteweater Engineering, McGraw Hill Inc, New York, NY, USA, 2003. 
[18] I. A. Şengil and M. Özacar, "The decolorization of C.I. Reactive black 5 in aqueous solution by electrocoagulation using sacrificial iron electrodes," Journal of Hazardous Materials, vol. 161, no. 2-3, pp. 1369-1376, 2009.

[19] S. Sánchez-Rodríguez, J. Trujillo-Reyes, E. Gutiérrez-Segura, M. Solache-Ríos, and A. Colín-Cruz, "Removal of indigo carmine by a Ni nanoscale oxides/Schoenoplectus acutus composite in batch and fixed bed column systems," Separation Science and Technology, vol. 50, no. 11, pp. 1602-1610, 2015.

[20] N. Ardhan, T. Ruttithiwapanich, W. Songkasiri, and C. Phalakornkule, "Comparison of performance of continuous-flow and batch electrocoagulators: A case study for eliminating reactive blue 21 using iron electrodes," Separation and Purification Technology, vol. 146, pp. 75-84, 2015.

[21] G. Moussavi, R. Khosravi, and M. Farzadkia, "Removal of petroleum hydrocarbons from contaminated groundwater using an electrocoagulation process: batch and continuous experiments," Desalination, vol. 278, no. 1-3, pp. 288-294, 2011.

[22] N. Daneshvar, A. Oladegaragoze, and N. Djafarzadeh, "Decolorization of basic dye solutions by electrocoagulation: an investigation of the effect of operational parameters," Journal of Hazardous Materials, vol. 129, no. 1-3, pp. 116-122, 2006.

[23] N. Ozbay and A. S. Yargic, "Factorial experimental design for Remazol Yellow dye sorption using apple pulp/apple pulp carbon-titanium dioxide co-sorbent," Journal of Cleaner Production, vol. 100, pp. 333-343, 2015.

[24] K. Ahmed, F. Rehman, C. T. G. V. M. T. Pires, A. Rahim, A. L. Santos, and C. Airoldi, "Aluminum doped mesoporous silica SBA-15 for the removal of remazol yellow dye from water," Microporous and Mesoporous Materials, vol. 236, pp. 167-175, 2016.

[25] C. Barrera-Diaz, Aplicaciones electroquímicas al tratamiento de aguas residuales, Editorial Reverte, 2016.

[26] N. Daneshvar, A. R. Khataee, A. R. Amani Ghadim, and M. H. Rasoulifard, "Decolorization of C.I. Acid Yellow 23 solution by electrocoagulation process: Investigation of operational parameters and evaluation of specific electrical energy consumption (SEEC)," Journal of Hazardous Materials, vol. 148, no. 3, pp. 566$572,2007$.

[27] S. Zodi, B. Merzouk, O. Potier, F. Lapicque, and J.-P. Leclerc, "Direct red 81 dye removal by a continuous flow electrocoagulation/flotation reactor," Separation and Purification Technology, vol. 108, pp. 215-222, 2013.

[28] M. Prica, S. Adamovic, B. Dalmacija et al., "The electrocoagulation/flotation study: the removal of heavy metals from the waste fountain solution," Process Safety and Environmental Protection, vol. 94, pp. 262-273, 2015.

[29] S. Zhang, J. Zhang, W. Wang, F. Li, and X. Cheng, "Removal of phosphate from landscape water using an electrocoagulation process powered directly by photovoltaic solar modules," Solar Energy Materials and Solar Cells, vol. 117, pp. 73-80, 2013.

[30] U. T. Un and E. Aytac, "Electrocoagulation in a packed bed reactor-complete treatment of color and cod from real textile wastewater," Journal of Environmental Management, vol. 123, pp. 113-119, 2013.

[31] C. A. Martínez-Huitle and E. Brillas, "Decontamination of wastewaters containing synthetic organic dyes by electrochemical methods: a general review," Applied Catalysis B: Environmental, vol. 87, no. 3-4, pp. 105-145, 2009.
[32] E. J. Lara-Vásquez, M. Solache-Riós, and E. Gutiérrez-Segura, "Malachite green dye behaviors in the presence of biosorbents from maize (Zea mays L.), their $\mathrm{Fe}-\mathrm{Cu}$ nanoparticles composites and $\mathrm{Fe}-\mathrm{Cu}$ nanoparticles," Journal of Environmental Chemical Engineering, vol. 4, no. 2, pp. 1594-1603, 2016.

[33] Ch. Djilani, R. Zaghdoudi, F. Djazi et al., "Adsorption of dyes on activated carbon prepared from apricot stones and commercial activated carbon," Journal of the Taiwan Institute of Chemical Engineers, vol. 53, pp. 112-121, 2015.

[34] X. Zhang, S. Zhang, B. Pan, M. Hua, and X. Zhao, "Simple fabrication of polymer-based Trametes versicolor laccase for decolorization of malachite green," Bioresource Technology, vol. 115, pp. 16-20, 2012.

[35] X. Bi, P. Wang, C. Jiao, and H. Cao, "Degradation of remazol golden yellow dye wastewater in microwave enhanced $\mathrm{ClO}_{2}$ catalytic oxidation process," Journal of Hazardous Materials, vol. 168, no. 2-3, pp. 895-900, 2009.

[36] F. Guenfoud, M. Mokhtari, and H. Akrout, "Electrochemical degradation of malachite green with BDD electrodes: Effect of electrochemical parameters," Diamond and Related Materials, vol. 46, pp. 8-14, 2014.

[37] T. B. Pushpa, J. Vijayaraghavan, S. J. Sardhar-Basha, V. Sekaran, K. Vijayaraghavan, and J. Jegan, "Investigation on removal of malachite green using EM based compost as adsorbent," Ecotoxicology and Environmental Safety, vol. 118, pp. 177-182, 2015.

[38] A. A. Jalil, S. Triwahyono, M. R. Yaakob et al., "Utilization of bivalve shell-treated Zea mays L. (maize) husk leaf as a lowcost biosorbent for enhanced adsorption of malachite green," Bioresource Technology, vol. 120, pp. 218-224, 2012.

[39] J. Trujillo-Reyes, V. Sánchez-Mendieta, M. José Solache-Ros, and A. Colín-Cruz, "Removal of remazol yellow from aqueous solution using $\mathrm{Fe}-\mathrm{Cu}$ and $\mathrm{Fe}-\mathrm{Ni}$ nanoscale oxides and their carbonaceous composites," Environmental Technology, vol. 33, no. 5, pp. 545-554, 2012.

[40] R. Gopinathan, A. Bhowal, and C. Garlapati, "Thermodynamic study of some basic dyes adsorption from aqueous solutions on activated carbon and new correlations," The Journal of Chemical Thermodynamics, vol. 107, pp. 182-188, 2017.

[41] N. Atar, A. Olgun, and S. Wang, "Adsorption of cadmium (II) and zinc (II) on boron enrichment process waste in aqueous solutions: Batch and fixed-bed system studies," Chemical Engineering Journal, vol. 192, pp. 1-7, 2012.

[42] T. Chen, B. Li, L. Fang, D.-S. Chen, W.-B. Xu, and C.-H. Xiong, "Response surface methodology for optimizing adsorption performance of gel-type weak acid resin for Eu(III)," Transactions of Nonferrous Metals Society of China, vol. 25, no. 12, pp. 42074215, 2015.

[43] I. Belbachir and B. Makhoukhi, "Adsorption of Bezathren dyes onto sodic bentonite from aqueous solutions," Journal of the Taiwan Institute of Chemical Engineers, vol. 75, pp. 105-111, 2017.

[44] M. A. Shavandi, Z. Haddadian, M. H. S. Ismail, and N. Abdullah, "Continuous metal and residual oil removal from palm oil mill effluent using natural zeolite-packed column," Journal of the Taiwan Institute of Chemical Engineers, vol. 43, no. 6, pp. 934941, 2012.

[45] E. Gutiérrez-Segura, A. Colín-Cruz, C. Fall, M. Solache-Ríos, and P. Balderas-Hernández, "Comparison of $\mathrm{Cd}-\mathrm{Pb}$ adsorption on commercial activated carbon and carbonaceous material from pyrolysed sewage sludge in column system," Environmental Technology, vol. 30, no. 5, pp. 455-461, 2009. 
[46] J. B. Lambert, H. F. Shurvell, D. A. Lightner, and R. G. Cooks, Organic Structural Spectroscopy, Prentice Hall Inc, Upper Saddle River, NJ, USA, 1998.

[47] S. S. Márquez-Mendoza, M. Jiménez-Reyes, M. Solache-Ríos, and E. Gutiérrez-Segura, "Fluoride removal from aqueous solutions by a carbonaceous material from pyrolysis of sewage," Water, Air, and Soil Pollution, vol. 223, no. 5, pp. 1959-1971, 2012. 

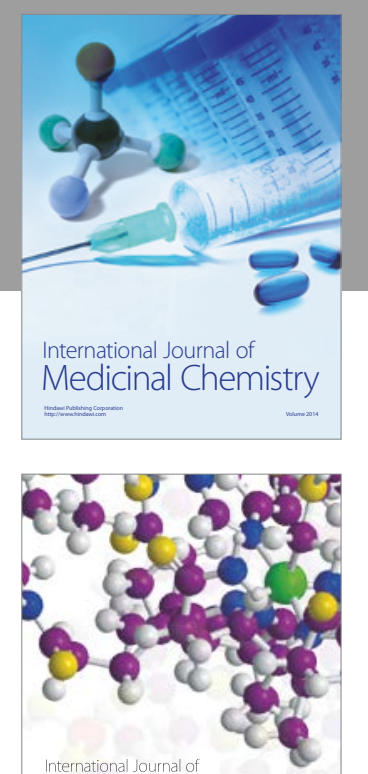

Carbohydrate Chemistry

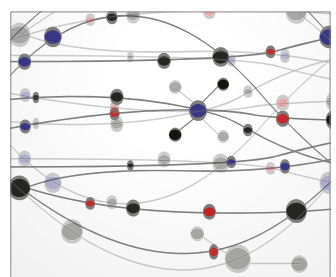

The Scientific World Journal
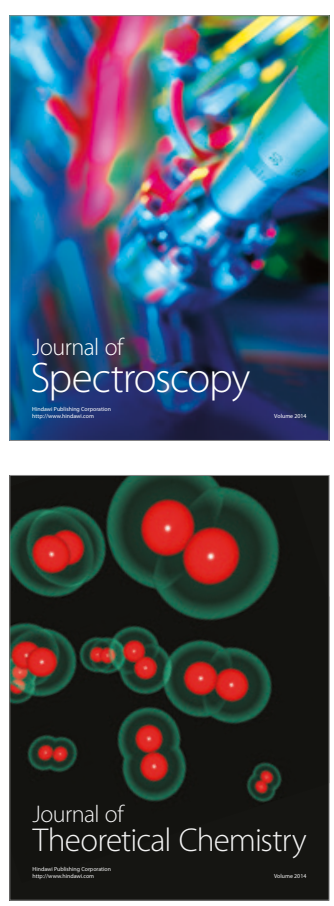
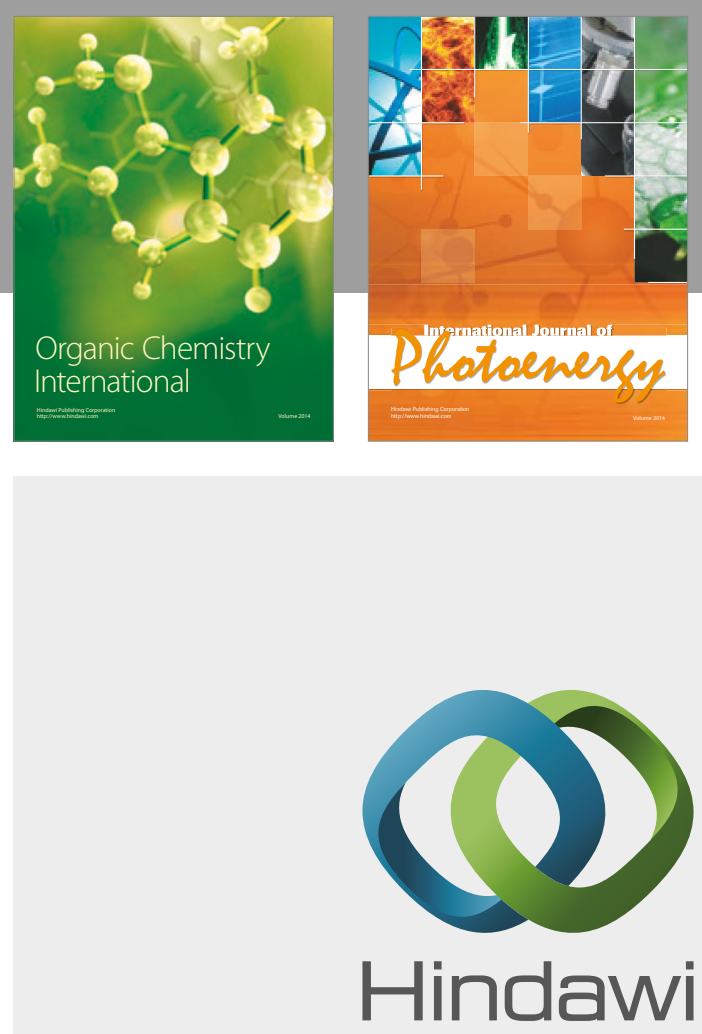

Submit your manuscripts at

https://www.hindawi.com

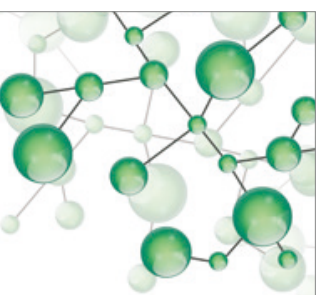

International Journal of

Inorganic Chemistry

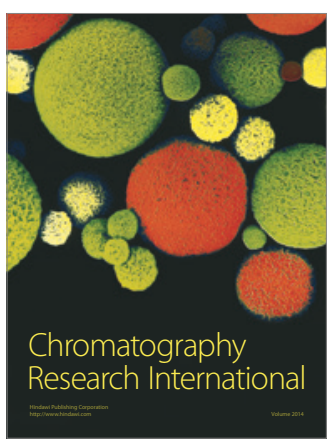

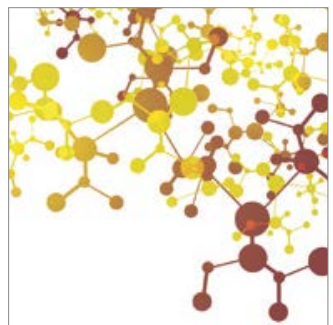

Applied Chemistry
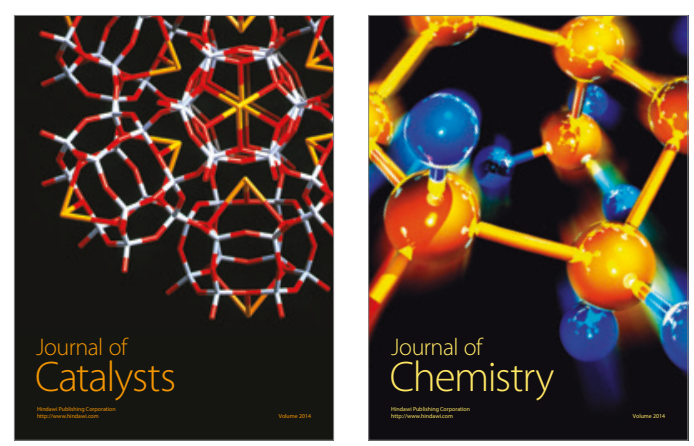
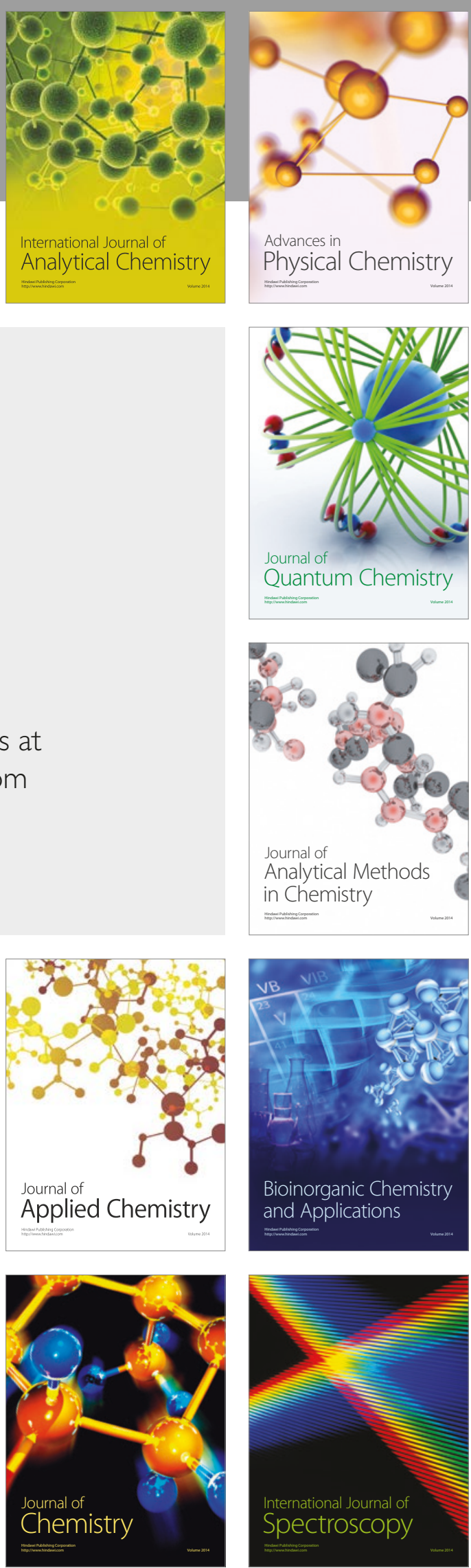